\title{
Courinate
}

\section{CARA PEMBUATAN BIOPESTISIDA DAUN PEPAYA}

\author{
Neti Kesumawati*, H. Masturi, \& Y. Armadi \\ Program Studi Agroekoteknologi, Fakultas Pertanian, Universitas Muhammadiyah Bengkulu \\ *Corresponding author: kesumawatineti30@gmail.com
}

\begin{abstract}
ABSTRAK
Pada umumnya penduduk Desa Perbo Kecamatan Curup Utara Kabupaten Rejang Lebong bermata pencaharian sebagai petani. Bercocok tanam merupakan andalan utama penopang kehidupan mereka, semakin banyak hasil produksi pertanian yang diperoleh maka semakin meningkat kesejahteraan masyarakat petani. Oleh karena itu, petani Desa Perbo Kecamatan Curup Utara selalu berusaha untuk meningkatkan hasil panennya melalui berbagai cara, antara lain pemakaian pestisida sintetik dalam pembrantasan hama penyakit. Mereka tidak menyadari bahwa pemakaian pestisida ini akan menimbulkan dampak negatif, seperti timbulnya berbagai penyakit yang menyerang manusia serta terjadinya pencemaran lingkungan. Mengingat hal tersebut di atas, maka perlu mengalihkan pemakaian pestisida sintetik menjadi pestisida alami. Cara yang paling efektif untuk mengalihkan perilaku masyarakat yang mengutamakan pemakaian pestisida kimia ini adalah melakukan penyuluhan/pelatihan, dimana metodenya terdiri dari : tentang kelebihan dan kekurangan pestisida berbahan dasar kimia dan pestisida alami (biopesitisida) serta pelatihan pembuatan biopestisida, terutama biopestisida daun pepaya. dimana metodenya terdiri dari : (1) Pendidikan dan penyuluhan tentang perlunya menjaga kelestarian lingkungan; kelebihan dan kekurangan pestisida berbahan dasar kimia dan pestisida alami (biopesitisida); serta bagaimana teknik pembuatan biopestisida daun pepaya; (2) Pelatihan cara pembuatan biopestisida yang bahan bakunya daun pepaya yang sangat berlimpah di Desa Perbo Kecamatan Curup Utara. Melalui kegiatan penyuluhan/pelatihan dalam rangka pengabdian masyarakat ini telah meningkatkan wawasan anggota kelompok wanita tani seputar pestisida sintetik dan dampak yang ditimbulkan terhadap lingkungan serta dalam membuat pestisida daun pepaya. Selanjutnya diharapkan dapat menekan biaya operasional dalam berusahatani serta meminimalisir pencemaran lingkungan akibat pemakaian pestisida sintetik.
\end{abstract}

\section{Kata Kunci : daun pepaya, pestisida nabati, pencemaran lingkungan}

\section{PENDAHULUAN}

\subsection{Latar Belakang}

Di zaman yang serba modern ini, perkembangan industri dan teknologi berjalan dengan pesat sehingga kenyamanan manusia semakin bertambah. Tetapi manusia tidak menyadari pengaruh buruk dari perkembangan industri dan teknologi bagi lingkungan hidup, seperti banyak pencemaran lingkungan yang terjadi dimana mana akibat pemakaian pestisida dan menjadi masalah besar bagi umat manusia. Hasilnya bahanbahan kimia yang terdapat di dalam pestisida merebak dan menjadi polutan bagi alam sehingga berpengaruh pada kehidupan manusia (Widyawati, 2013)

Dewasa ini, residu bahan kimia dari pestisida sintetik di Desa Perbo Kecamatan Curup Utara telah mempengaruhi penduduk di daerah tersebut, baik secara langsung maupun tidak langsung. Berbagai penyakit telah ditimbulkan dari pemakaian pestida 
sintetik dalam rangka pembrantasan hama penyakit, seperti kanker, stroke, ginjal, dll. Menurut World Health Organization (WHO), paling tidak 20.000 orang per tahun, mati akibat keracunan pestisida. Diperkirakan $5.000-10.000$ orang per tahun mengalami dampak yang sangat fatal, seperti mengalami penyakit kanker, cacat tubuh, kemandulan dan penyakit liver. Walaupun demikian, pemakaian pestisida sintetik di daerah ini semakin merajalela, bahkan dianggap sebagai dewa penyelamat dalam usaha bercocok tanam. Hal terlihat dari perilaku masyarakat petaninya yang memanfaatkan produk ini tanpa memperhatikan batas ambang ekonomi keberadaan hama penyakit. Oleh karena itu, perlu usaha untuk mengurangiketergantungan masyarakat petani akan pestisida sintetik dengan cara mengalihkan pemakaian pestisida sintetik menjadi pestisida alami, yaitu pestisida yang bahan dasarnya berasal dari tumbuhan, mempunyai kandungan bahan aktif yang dapat mengendalikan serangga hama (Saenong, 2016), seperti daun pepaya.

Daun pepaya (Carica papaya) mengandung berbagai macam zat, antara lain : vitamin A 18250 SI, vitamin 810,15 mg, vitamin C $140 \mathrm{mg}$, kalori $79 \mathrm{kal}$, protein 8,0 g, lemak 2 g,hidrat Arang 11,9 g, kalsium 353 $\mathrm{mg}$, fosfor $63 \mathrm{mg}$, besi $0,8 \mathrm{mg}$, air $75,4 \mathrm{~g}$, papayotin, kautsyuk, karpain, karposit. Daun pepaya memiliki kandungan papain yang cukup efektif dalam mengendalikan hama dan ulat penghisap tanaman (Ferayanti, 2013). Senyawa daun pepaya yang mengandung mengandung bahan aktif "Papain", sangat efektif untuk mengendalikan ulat dan hama penghisap (Juliantara, 2010).

Desa Perbo Kecamatan Curup Utara merupakan daerah yang sangat subur sehingga banyak dijumpai usaha tani dengan berbagai komoditas pertanian, salah satunya tanaman pepaya. Menurut BPP (2016), luas tanam tanaman pepaya seluas 21,05 ha dengan produksi sebanyak 385 ton. Oleh karena itu, untuk memperoleh daun pepaya sebagai bahan baku pembuatan biopestisida tidak merupakan hambatan bagi masyarakat petani di daerah tersebut. Apabila daun pepaya ini dimanfaatkan secara maksimal dalam pembuatan biopestisida akan mengurangi biaya usahatani karena tidak perlu mengeluarkan biaya untuk membeli pestisida sintetik. Selain itu, pencemaran lingkungan akibat pemakaian pestisida sintetik dapat diminimalisir. Fachraniah, Kurniasih dan Azha (2017), beberapa keunggulan dari pestisida alami, antara lain : (1) Mudah terurai di alam dan ramah lingkungan: (2) Relatif aman bagi manusia dan ternak karena residunya mudah hilang; (3) Dapat membunuh hama/penyakit tanaman (ekstrak daun pepaya, tembakau, biji mahoni, dsb); (4) Sebagai pengumpul/perangkap hama tanaman (tanaman orok-orok, temblek ayam); (5) Bahan baku mudah didapat dan ekonomis: (6) Dosis yang digunakan tidak mengikat dan beresiko dibandingkan dengan penggunaan pestisida sintetis; (7) Merupakan pemecahan masalah hama jangka pendek/cepat.

Berdasarkan permasalahan di atas, perlu dilakukan penyuluhan dan pelatihan pembuatan pestisida daun pepaya bagi masyarakat petani di Desa Perbo Kecamatan Curup Utara yang diwakili oleh kelompok wanita tani "Mawari" Para anggota ini diharapkan menjadi informan kunci untuk petani lainnya. Pelatihan ini bertujuan untuk meningkatkan pengetahuan dan keterampilan dalam membuat biopestisida daun pepaya. Selain itu, pembuatan pestisida ini secara teknis mudah dan murah sehingga dapat menekan biaya operasional para anggota kelompok wanita tani dalam bercocok tanam nantinya. Disamping itu, pelatihan ini dapat meningkatkan wawasan anggota kelompok wanita tani Mawar khususnya dan masyarakat petani umumnya tentang arti penting menjaga kelestarian lingkungan melalui pertanian yang ramah lingkungan yang lebih mengandalkan bahan-bahan alam dalam kegiatan bercocok tanam (Nurzaman, dkk. 2011).

\subsection{Rumusan Permasalahan}

a. Pemakaian pestisida sintetik telah 


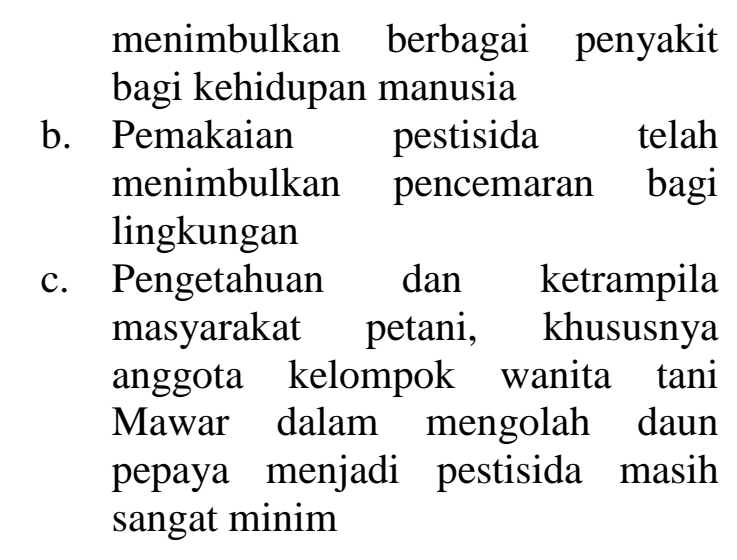

\section{METODE PELAKSANAAN}

\subsection{Solusi Permasalahan Kelompok Wanita Tani Mawar}

Dewasa ini, krisis lingkungan akibat pemakian pestisida sintetik sudah mencapai tahap yang tidak bisa ditolerir. Kondisi ini terjadi pada daerah-daerah pertanian yang ketergantungan pada pestisida dalam pengendalian hama penyakit sangat tinggi, termasuk Desa Perbo Kecamatan Curup Utara. Perilaku masyarakat ini harus dirubah dengan mengalihkan pemakian pestisida sintetik menjadi pestisida alami dengan memanfaatkan potensi daerah yang ada. Sementara di Desa Perbo Kecamatan Curup memiliki banyak tanaman pepaya, dimana daunnya belum dimanfaatkan secara maksimal menjadi pestisida. Keterbatasan informasi menjadi salah satu penyebab kelompok wanita tani Mawar tidak memiliki ketrampilan untuk mengolah daun pepaya menjadi pestisida. Maka perlu dilakukan penyuluhan dan pelatihan, berupa sentuhan teknologi yang mudah, murah, mudah dilaksanakan dan berbasis pada potensi lokal.

\subsection{Tahapan Pelaksanaan Pengabdian Masyarakat}

Tri Dharma perguruan tinggi merupakan tiga pilar dasar pola pikir dan menjadi kewajiban bagi tenaga pengajar sebagai kaum intelektual di negara Indonesia, termasuk tenaga pengajar Prodi
Agroteknologi Fakultas Pertanian Universitas Muhammadiyah Bengkulu. Salah satu pilar Tri Dharma perguruan tinggi adalah pengabdian masyarakat, baik dalam bentuk penyuluhan, pelatihan maupun gabungan dari keduanya. Pada kesempatan ini, pengabdian masyarakat dilaksanakan pada kelompok wanita tani Mawar Desa Perbo Kecamatan Curup Utara Kabupaten Rejang Lebong dari tanggal 6 Agustus 2018 sampai dengan 12 Agustus 2018. Supaya kegiatan pelaksanaan pengabdian masyarakat dapat berjalan efesien dan efektif maka dilakukan dengan beberapa tahapan, sebagai berikut :

a. Pendidikan dan Penyuluhan

Agar wawasan anggota kelompok Wanita tani Mawar mengeanai pestisida sintetik dan pestisida alami meningkat serta mengetahui cara pembuatan biopestisida daun pepaya secara teori

b. Pelatihan

Pada kegiatan ini, anggota Kelompok wanita tani langsung mempraktekkan cara pembuatan biopestisida daun pepaya yang langsung dipandu oleh tim penyuluh/pengabdi

\section{c. Pengaplikasian}

Pada kegiatan ini, anggota kelompok wanita tani didampingi untuk mempraktekkan pemakaian biopestisida daun pepaya pada lahan pertanian

\subsection{Cara Kerja Pembuatan Biopestisida Daun Pepaya}

Tabel. 1. Bahan dan peralatan pembuatan biopestisida daun pepaya

\begin{tabular}{lll}
\hline No & \multicolumn{1}{c}{ Bahan } & Alat \\
\hline 1. & 2 lb daun pepaya & Blender \\
2. & 4 l air & Pisau \\
3. & & \\
4. & Putung rokgam tembakau & Baskom \\
& & Saringan
\end{tabular}


Proses pembuatan biopestisida daun pepaya :

a. Siapkan daun pepaya sebanyak 2 lembar

b. Tumbuk daun pepaya hingga halus

c. Hasil tumbukan/rajangan direndam di dalam 4 liter air

d. Tambahkan 1 genggam daun tembakau/putntung rokok

e. Hasil campuran didiamkan semalam

f. Saring larutan hasil perendaman dengan kain halus.

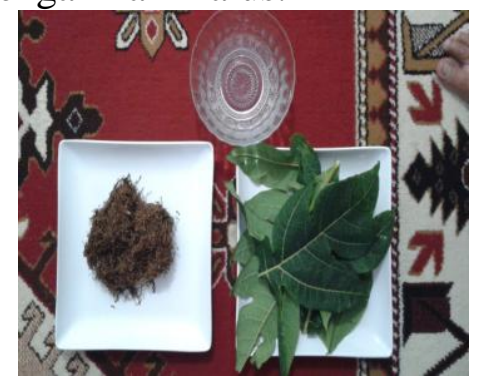

Gambar 1. Bahan-bahan pembuatan biopestisida daun pepaya

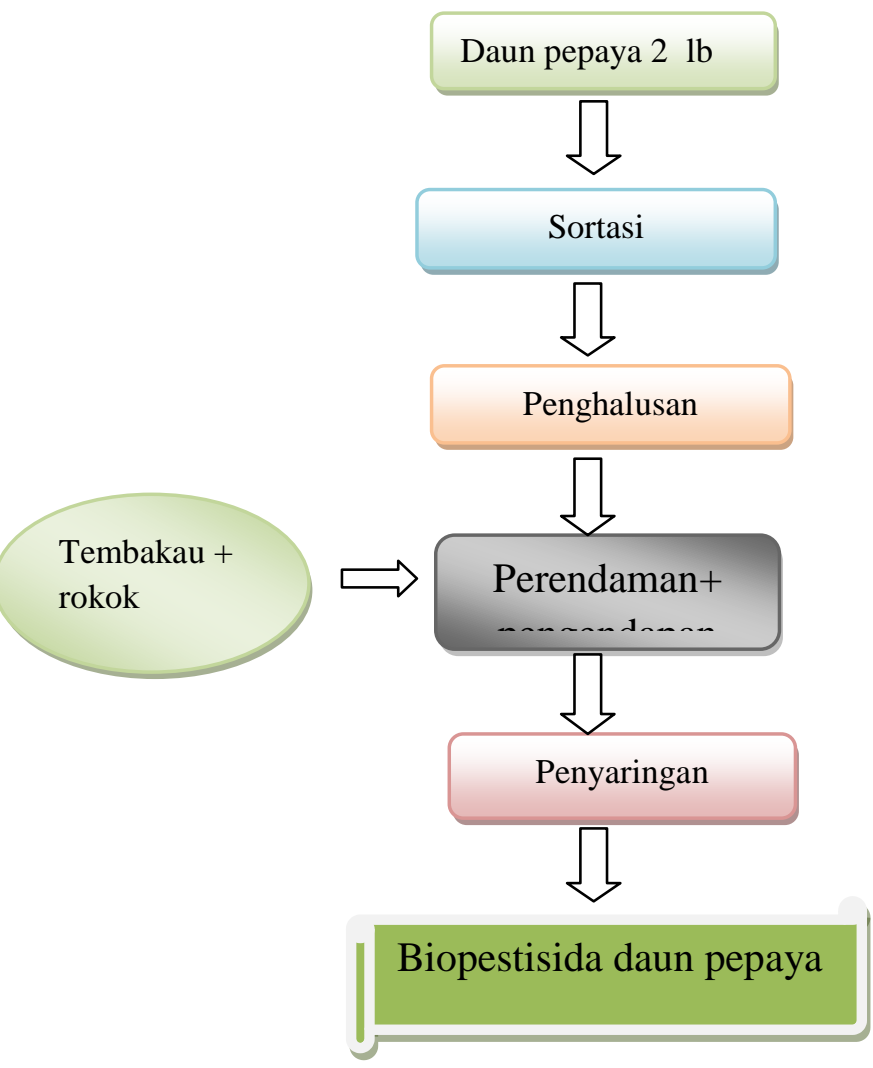

Gambar 2. Diagram alir pembuatan pestisida daun pepaya

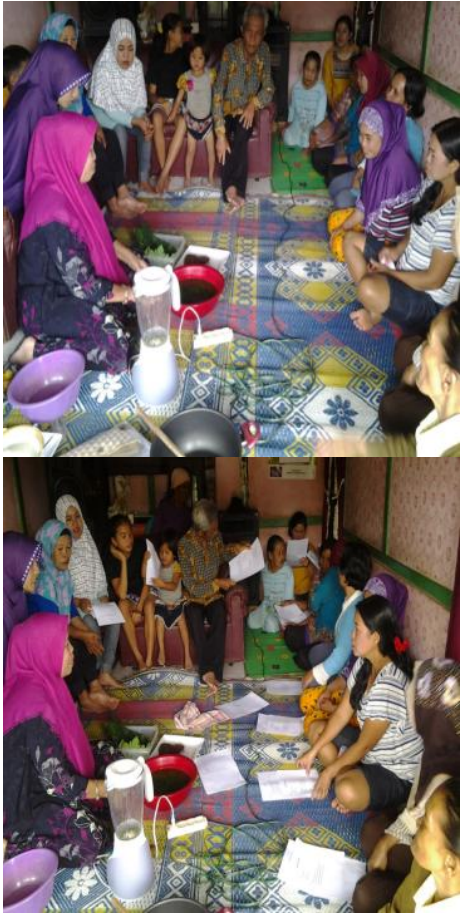

Gambar 3. Proses pelatihan pembuatan biopestisida daun pepaya

\section{HASIL DAN PEMBAHASAN}

Pelaksanaan kegiatan Tri Dharma perguruan tinggi berupa pengabdian kepada masyarakat pada kelompok wanita tani (KWT) Mawar Kecamatan Curup Utara Kabupaten Rejang Lebong" yang mengikutsertakan sebagian dari anggota kelompok wanita tani Mawar dilaksanakn pada tanggal 6 Agustus 2018 sampai dengan 12 Agustus 2018. Dipilihnya sebagian anggota kelompok wanita tani bertujuan agar penyampaian informasi bisa berjalan lebih efektif dan efisien dan anggota kelompok wanita tani yang terpilih diharapkan menjadi informan kunci yang akan menyampaikan pengetahuan dan ketrampilan yang diterimanya pada saat mengikuti kegiatan pengabdian masyarakat, baik penyuluhan maupun pelatihan.

Pada tahap awal pelaksanaan kegiatan masyarakat dilakukan koordinasi dengan anggota kelompok wanita tani Mawar untuk menentukan materi penyuluhan/pelatihan serta merancang penetapan waktu maupun 
tempatnya. Untuk tempat pelaksanaan kegiatan tidak menjadi permasalahan karena terdapat Balai Desa yang biasa digunakan untuk berbagai pertemuan. Tetapi penentuan waktu menjadi pembicaran yang agak alot karena pada umumnya anggota kelompok wanita tani ini bermatapencaharian sebagai petani yang hampir seluruh waktunya dalam sehari dihabiskan di kebun/ladang mereka. Walaupun demikian, penentuan waktu berjalan cukup lancar karena berkat komunikasi yang berjalan baik antara tim penyuluh/pengabdi dengan anggota kelompok wanita tani yang terpilih sebagai peserta kegiatan pengabdian masyarakat. Apalagi mereka menyadari informasi yang akan disampaikan para penyuluh/pelatih sangat berguna dalam hal pengendaliaan hama penyakit tanaman.

Hama dan penyakit merupakan organisme penganngu tanaman yang menyerang tanaman telah menjadi momok yang menakutkan bagi masyarakat petani di Desa Perbo, karena mereka sering mengalami gagal panen akibat serangan hama dan penyakit ini. Salah satu solusi yang dianggap ampuh dalam pengendalian hama dan penyakit ini adalah pemakaian pestisida kimia, yaitu pestisida yang bahan bakunya terdiri dari bahan kimia yang bermanfaat dalam pengendaliaaan organisme penggagu tanaman yang merugikan manusia, baik secara langsung maupun tidak langsung. Cara kerja pestisida kimia ini adalah dengan menghambat pertumbuhan/perkembangan, tingkah laku, perkembangbiakan, kesehatan, pengaruh hormon, penghambat makanan, membuat mandul, sebagai pengikat penolak dan aktivitas lainnya (Yuantari, 2016)

Pestisida kimia bagi sebagian besar masyarakat petani Desa Perbo, khususnya anggota kelompok wanita tani Mawar dianggap sebagai dewa penolong yang sangat membantu dalam pengendalian hama penyakit yang menyerang tanaman. Alazari (2013), menyatakan sebahagian besar petani, beranggapan pestisida adalah sebagai "dewa penyelamat" yang sangat vital. Sebab dengan bantuan pestisida, petani meyakini dapat terhindar dari kerugian akibat serangan jasad pengganggu tanaman yang terdiri dari kelompok hama, penyakit maupun gulma. Oleh karena itu, pemakaian pestisida kimia tersebut bagi masyarakat Desa Perbo kadang-kadang tidak mengikuti aturan dosis yang direkomendasikan Mereka tidak menyadari bahwa pestisida kimia ini berdampak negatif bagi lingkungan, seperti menimbulkan residu pestisida pada pada tanaman relatif tinggi, biaya produksi meningkat, bahaya terhadap kesehatan pekerja, menyebabkan pencemaran lingkungan (Cesnik et al., 2006).

Untuk itu, perlu sekali merubah perilaku masyarakat petani Desa Perbo yang mendewakan pestisida kimia dalam pengendaliaan hama dan penyakit untuk beralih pada pestisida alami (biopestisida), yaitu suatu pestisida yang memanfaatkan bahan-bahan alami yang ada di sekitar kita yang mempunyai banyak keunggulan, seperti : (1) Mudah terurai di alam dan ramah lingkungan; (2) Relatif aman bagi manusia dan ternak karena residunya mudah hilang; (3) Dapat membunuh hama/penyakit; (4) Sebagai pengumpul/perangkap hama tanaman; (5) Bahan baku mudah didapat dan ekonomis; (6) Dosis yang digunakan tidak mengikat dan beresiko dibandingkan dengan penggunaan pestisida sintetis; (7) Merupakan pemecahan masalah hama jangka pendek/cepat (Fachraniah, 2017)

Berhubunga Desa Perbo merupakan daerah pertanian yang banyak sekali dijumpai potensi sumberdaya alam yang bisa dimanfaatkan sebagai pestisida alami, salah satunya adalah daun pepaya. Maka materi yang dipilih dalam rangka kegiatan pengabdian masyarakat "yaitu " Cara Pembuatan Biopestisida Daun Pepaya“ Sebelum melakukan pelatihan pembuatan biopestisida ini, anggota kelompok wanita tani Mawar dibekali dengan ilmu pengetahuan tentang perlunya menjaga kelestarian lingkungan hidup dengan menggunakan pestisida yang ramah 
lingkungan serta dampak negatif yang ditimbulkan dari pemakaian pestisida kimia. Semua ini bertujuan untuk membuka pikiran meraka bahwa betapa bahayanya dampak dari pemakaian pestisida kimia sehingga berkeinginan untuk beralih ke pesisida alami (biopestisida)

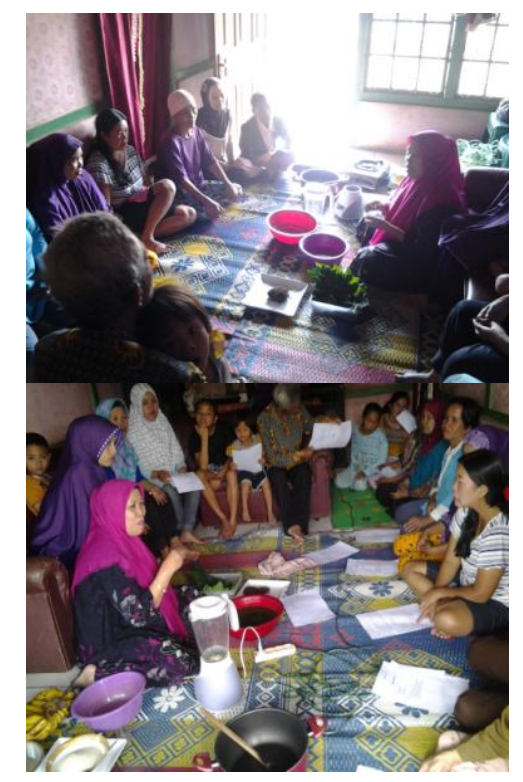

Gambar 4. Peserta sedang mendengar paparan tim penyuluh

Berdasarkan evaluasi selama berlangsungnya kegiatan pengabdian masyarakat berjalan sukses, yaitu sebagai berkut :

1. Kelompok wanita tani Mawar dapat mengaplikasikan teknologi pengolahan daun pepaya menjadi pestisida yang menjadi alternatif penganti pestisida sintetik. Dengan adanya pestisida ini akan mampu meminimalisir pencemaran lingkungan yang menjadi perhatian semua pihak.

2. Terjadi peningkatan pengetahuan dan ketrampilan pembuatan pestisida daun pepaya dari kelompok wanita tani Mawar

3. Terjadi peningkatan wawasan mengenai arti pentingnya menjaga kelestarian lingkungan dari kelompok wanita tani
Mawar

4. Kegiatan ini memotivasi seluruh masyarakat petani lainnya yang ada di Kecamatan Curup Utara untuk memanfaatkan daun pepaya menjadi pestisida

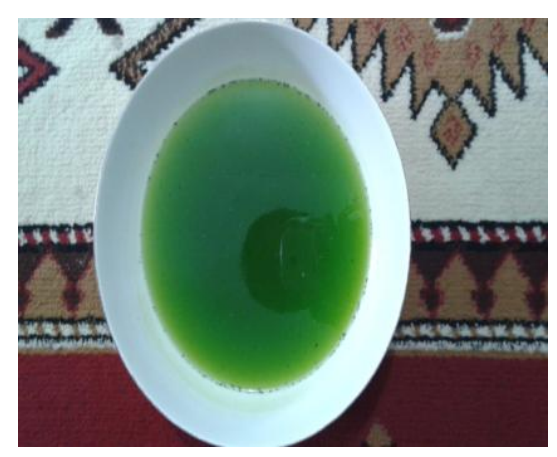

Gambar 5. Biopestida daun pepaya

\section{KESIMPULAN DAN SARAN}

\subsection{Kesimpulan}

1. Kegiatan pengabdian masyarakat berhasil memberi pengertian terhadap KWT Mawar bahwa sangat penting menjaga kelestarian lingkungan

2. Kegiatan pengabdian masyarakt direspon dengan baik oleh anggota KWT Mawar terhadap semua kegiatan yang telah dirancang oleh tim pengabdi

3. Pelaksanaan kegiatan pengabdian masyarakat berhasil meningkatkan wawasan anggota KWT dalam hal pengolahan daun pepaya menjadi biopestisida daun pepaya

\subsection{Saran}

1. Perlu penyuluhan/ pelatihan pembuatan biopestisida yang lebih variatif yang bahan bakunya banyak terdapat di sekitar kita, contoh daun manggis, bawang putih, kulit jengkol, dll

2. Bagi anggota KWT Mawar bisa berfungsi sebagai informan kunci dalam penyebaran pengetahuan dan 
ketrampilan tentang pengolahan daun pepaya menjadi biopestisida

\section{DAFTAR PUSTAKA}

Alazari. 2013. Dampak Negati Penggunaan Pestisida. Program Studi Agroteknologi. Fakultas Pertanian Universitas Hasanuddin Makasar

BPP. 2016. Programa BPP Kesambe Lama Tahun 2016. Kecamatan Rejang Lebong

Cesnik H.B., A. Gregorcic, S.V. Bolta, V. Kmecl. 2006. Monitoring of Pesticide Residues In Apples, Lettuce And Potato of The Slovene Origin, 200104. Food Additives and Contaminants 23(2): $164-173$

Girsang, W. 2009. Dampak Negatif

Pemakaian Pestisida. Fakultas

Pertanian USI Siantar

Fachraniah; Kurniasih, E dan Azha, M. 2017. Pestisida Alami Dari Daun Daun

Batang Pepaya. Jurusan Teknik Kimia Politeknik Negeri Lhokseumawe

Nurzaman, M., Mutaqin, A.Z. dan Wulandari, A.P. 2011. Pemanfaatan Bawang Merah Dan Bawang Putih Untuk Pestisida Nabati Di Desa Cipanas Dan Desa Nangelasari Kecanmatan Cipatujah Kabupaten Tasikmalaya. FMIPA, Universitas Padjadjaran

Saenong, M.S. 2016. Tumbuhan Indonesia Potensial Sebagai Insektisida Nabati Untuk Mengendalikan Hama Kumbang Bubuk Jagung (Sitophilus spp.) Litbang Pertanian, 35(3): 131142

Ferayanti, P. 2013. Pestisida Nabati Daun Pepaya. Serambi Pertanian BTTP Aceh. Volume VII/No. 21/

Juliantara, K. 2010. Informansi Tanaman Hias Indonesia. Pemanfaatan Ekstrak Daun Pepaya (Carica papaya) Sebagai Pestisida Alami Yang Lingkunga

Widyawati, A.D. 2013. Pencemaran Lingkungan Jurusan Kurikulum dan
Teknologi Pendidikan Fakultas Ilmu Pendidikan Universitas NegeSemarang

Yuantari, M.C. 2016. Dampak Pestisida Organoklorin Terhadap Kesehatan Manusia dan Lingkungan Serta Penanggulangannya. Fakultas Kesehatan Universitas Dian Nuswantoro Semarang 